\title{
Masculinities in Old Norse Literature. Eds. Gareth Lloyd Evans, Jessica Clare Hancock. Cambridge, D.S. Brewer, 2020, ss. 285
}

Książka Masculinities in Old Norse Literature, zredagowana przez Garetha Lloyda Evansa i Jessicę Clare Hancock, to zbiór dwunastu ciekawych artykułów na temat obliczy męskości w literaturze staronordyckiej. Wybrane teksty pomieszczone $\mathrm{w}$ tomie zaprezentowano pierwotnie podczas międzynarodowego kongresu mediewistycznego w Leeds w lipcu 2017 roku (International Medieval Congress). Recenzowana książka została podzielona na trzy symetryczne bloki tematyczne, zogniskowane wokół problematyki związanej z formowaniem się tożsamości mężczyzny (Becoming Masculine), męską wrażliwością i współzależnością między męskością a władzą (Masculinity, Power, and Vulnerability) oraz relacjami między mężczyznami (Men's Relationships). Zasadniczą część pracy poprzedza kilkunastostronicowy wstęp, a wieńczą ją posłowie i obszerna bibliografia, składająca się z prawie trzystu pięćdziesięciu pozycji. Redaktorzy anonsują tom jako pierwsze zbiorowe studium nad mężczyznami i męskościami na gruncie literatury staronordyckiej (s. 18). W istocie, o ile kwestia kobiet i kobiecości w tej unikalnej literaturze doczekała się kilku syntetycznych — indywidualnych i zbiorowych — opracowań ${ }^{1}$, o tyle w przypadku staronordyckich męskości rzecz ma się nieco ubożej, choć od kilku lat czynione są usilne starania, by wypełnić tę lukę badawczą. Skądinąd prym wiedzie $\mathrm{w}$ tym jeden $\mathrm{z}$ redaktorów omawianej książki, który naświetlił to zagadnienie w pracy poświęconej islandzkim sagom rodowym².

${ }^{1}$ Zob. m.in.: J. Jochens: Women in Old Norse Society. Ithaca-London 1995; Cold Counsel: Women in Old Norse Literature and Mythology. Eds. S.M. Anderson, K. Swenson. New York-London 2002; Jóhanna Katrín Friðriksdóttir: Women in Old Norse Literature. Bodies, Words, and Power. New York 2013.

${ }^{2}$ G.L. Evans: Men and Masculinities in the Sagas of Icelanders. Oxford 2019. Zob. też w tej sprawie: „Limes. Studia i materiały z dziejów Europy Środkowo-Wschodniej” 2020, nr 13 
Na korpus analityczny składają się heroiczne pieśni Eddy poetyckiej oraz wybrane sagi rodowe, rycerskie, królewskie, biskupie, legendarne i współczesne, acz wskazać trzeba, że ten ostatni podgatunek piśmiennictwa staronordyckiego został bodaj najsłabiej wyeksponowany w recenzowanym tomie. Biorąc na warsztat męskocentryczny i patriarchalny świat staronordyckich sag, autorzy szkiców skwapliwie odwołują się do kluczowych pojęć i teorii spod znaku men's studies, takich jak choćby męskość hegemoniczna (hegemonic masculinity), męskość inkluzywna (inclusive masculinity), męskość kobieca (female masculinity) — dwa ostatnie terminy pojawiają się w tytułach artykułów ${ }^{3}$. O ile odczytywanie literatury średniowiecznej przez pryzmat współczesnych koncepcji socjologicznych nie zawsze jest zamierzeniem trafnym i płodnym badawczo, głównie ze względu na duże ryzyko anachronizmu, o tyle autorom poszczególnych artykułów zamieszczonych w tomie nie można postawić zarzutu o niewłaściwe bądź przesadne wykorzystanie wzmiankowanej teoretycznej podbudowy. Wypada dodać, że męskość w książce pod redakcją G.L. Evansa i J.C. Hancock rozumiana jest jako konstrukt społeczny, będący wynikiem powtarzających się aktów performatywnych, polegających na przypisywaniu mężczyznom stałych predyspozycji związanych z płcią w zakresie danej kultury. Redaktorzy dowodzą, że w literaturze staronordyckiej współistnieje wiele różnych typów męskości (s. 4), dlatego też posługują się — acz są odstępstwa od tej reguły ${ }^{4}$ - liczbą mnogą w odniesieniu do męskości w kontekście społeczno-kulturowym (Old Norse masculinities) i rodzajowym (np. clerical masculinities), liczbą pojedynczą zaś — w kontekście strukturalnym (np. hegemonic masculinity).

Część właściwą omawianego tomu otwiera artykuł Orena Falka Boyhood, Saga-Style: From Mannsefni to Maðr, poświęcony mechanizmom socjalizacji. Bazując na wybranych sagach rodowych i współczesnych, autor ujmuje dzieciństwo i okres młodzieńczy jako początkowe stadium męskości (masculinityin-the-making - s. 35). Przejście od mannsefni do maðr, czyli przeistoczenie się chłopca mającego zadatki na mężczyznę w prawdziwego mężczyznę, to żmudny proces edukacyjny, którego zasadniczym celem był rozwój potencjału męskiego chłopców (potential masculinity — s. 22) i wykształcenie w nich określonych cech osobowości mężczyzny, tj. heroizmu, niezależności, samowystarczalności, uporu, nieustępliwości. Edukacja chłopca, mająca przygo-

(numer pod redakcją R. Gogosza, poświęcony w całości zagadnieniom męskości w literaturze i kulturze staronordyckiej).

3 Autorzy odwołują się m.in. do następujących prac: E. Kosofsky Sedgwick: Between Men: English Literature and Male Homosocial Desire. New York 1985; R. Connell: Masculinities. Cambridge 1995; J. Halberstam: Female Masculinity. Durham 1998; E. Anderson: Inclusive Masculinity: The Changing Nature of Masculinities. New York 2009.

${ }^{4} \mathrm{Na}$ swoisty galimatias terminologiczny w anglojęzycznych pracach na temat męskości wskazywał K. Kłosiński: De(re)konstrukcja męskości. „Teksty Drugie” 2015, nr 2, s. 11-29. 
tować go do roli mężczyzny, leżała w gestii męskiego członka rodziny oraz obejmowała szereg aktywności fizycznych i intelektualnych, takich jak, dla przykładu, nauka władania bronią, gry sportowe, publiczne wystąpienia, praca fizyczna etc. Jak zauważa O. Falk, mimo że dla wielu bohaterów sag mannsefni jest jedynie fazą przejściową, swoistą zaprawą do roli maðr, to jednak transformacja ta nie zawsze kończy się sukcesem, a jej efektem ubocznym są częstokroć agresywne i antyspołeczne zachowania.

W kolejnym szkicu, The Licit Love Visit: Masculine Sexual Maturation and the 'Temporary Troll Lover' Trope pióra Matthew Roby'ego, poruszono natomiast temat męskiej inicjacji seksualnej (z kobietą-trollem) w trzech sagach legendarnych (Örvar-Odds saga, Hálfdanar saga Brönufóstra, Ketils saga hoengs) oraz jednej sadze rodowej (Kjalnesinga saga). Autor argumentuje, że sagi te opierają się na podobnym schemacie fabularnym: początkowo pasywni i niewprawni młodzi protagoniści ulegają zachętom kobiet-trolli do kontaktu seksualnego, podczas którego przejmują inicjatywę i odgrywają dominującą rolę, by ostatecznie powrócić do swoich „ziemskich” wybranek i je poślubić. M. Roby dostrzega w tych epizodach symboliczny obrzęd przejścia, umożliwiający młodemu bohaterowi osiągnięcie dojrzałości seksualnej poprzez przemianę z chłopca w kochanka oraz wykształcenie cech dominującego mężczyzny (dominant masculinity — s. 37). Wedle jego wykładni przedmałżeńskie romanse protagonistów sag z kochankami-trollami, symbolizującymi kobiety niższego stanu (s. 52), można odczytywać jako etap przygotowawczy do małżeństwa, mający na celu aktywowanie potencjału seksualnego młodego mężczyzny. Badacz dochodzi do wniosku, że tylko autor Ketils saga hoengs kwestionuje stosowność tego rodzaju praktyk, sugerując, że „przedmałżeńskie eksperymentowanie seksualne jest niesprawiedliwym, nieskutecznym i emocjonalnie szkodliwym wzorem do osiągnięcia męskiej dojrzałości”’.

Gareth Lloyd Evans w tekście Female Masculinity and the Sagas of Icelanders odświeża dobrze znaną z sag rodowych kwestię „męskich” kobiet, proponując nowe odczytanie trzech sugestywnych epizodów z udziałem Auðr (Laxdcela saga), Ólof (Víglundar saga) oraz Freydís (Eiriks saga rauða). Protagonistki wchodzą w rolę mężczyzn (performance of masculinity — s. 67), imitując męski sposób zachowania oraz wykorzystując męskie ubranie i akcesoria (np. miecz), by uchronić się przed przemocą fizyczną i seksualną bądź dokonać zemsty. G.L. Evans poczytuje te działania za krytykę konwencjonalnych, usankcjonowanych kulturowo norm i zachowań przypisanych mężczyznom, opartych na agresji i dominacji (critique of male masculinity — s. 69). Dowodzi on nadto, że męskość nie jest zarezerwowana li tylko dla mężczyzn;

5 „Premarital sexual experimentation is an inequitable, ineffective, and emotionally injurious model for the accession to male adulthood" (s. 57). 
wręcz przeciwnie: kobiece postaci mogą niekiedy skuteczniej i wymowniej odgrywać rolę mężczyzn aniżeli postaci męskie (s. 69). Autor twierdzi, że Auðr, Ólof i Freydís wcielają się w mężczyzn, zachowując status kobiet w sensie biologicznym, czym destabilizują pozorną nierozerwalność relacji mężczyzna męskość i poszerzają jej zakres o męskość kobiecą.

W zbliżonym kręgu tematycznym pozostaje Jóhanna Katrín Friðriksdóttir w 'With mirthful merriment': Masquerade and Masculinity in Mágus saga jarls, która eksploruje naturę dworskiej męskości w jednej z sag rycerskich. Jóhanna wskazuje, że redaktor Mágus saga jarls, zachowanej w ponad siedemdziesięciu manuskryptach, występuje z „krytyką homospołecznego dworu króla Karla" ", a czyni to za pośrednictwem Mágusa, który dzięki licznym przebraniom i magicznym umiejętnościom szlachetnie niesie pomoc prześladowanym przez króla braciom. Mágus, jako mężczyzna nienormatywny (non-normative man - s. 84), pozostaje w sprzeczności z dominującym wzorcem męskości, charakteryzującym się m.in. agresją fizyczną i werbalną, ambicjonalnością oraz przeczuleniem na punkcie własnego honoru. Ponadto, jak przekonuje Jóhanna, saga poddaje ostrej krytyce wszelkie przejawy toksycznej męskości (toxic masculinity — s. 90), z mizoginicznym uprzedmiotowieniem kobiet na czele. Rzecznikiem tych idei jest Ermenga, która zawłaszcza męską tożsamość, przejmując męski ubiór i modus operandi, a także używając męskiego imienia Hirtingr, by wykonać z pozoru niewykonalne zadania powierzone jej przez męża i władać dworem w jego zastępstwie.

Osią następnego artykułu, Vulnerable Masculinities and the Vicissitudes of Power in Göngu-Hrólfs saga autorstwa Philipa Lavendera, są niepełnosprawność jako wyzwanie dla męskości oraz wpływ aktów mowy, takich jak przysięgi, obietnice, żądania czy deklaracje, na pozbawienie antagonisty autonomii i władzy. Wygórowane wymagania stawiane mężczyznom w średniowiecznej Islandii wiązały się z koniecznością nieustannego, wręcz desperackiego potwierdzania męskości (desperate masculinity - s. 100) w obawie przed marginalizacją i osunięciem się w hierarchii społecznej. Sprawny fizycznie mężczyzna uosabiał siłę i niezależność, mężczyzna dotknięty kalectwem jawił się zaś jako bezsilny i podległy. Jak spostrzega Ph. Lavender, mimo że Hrólfr tytułowy bohater sagi legendarnej, która znalazła się pod jego lupą — został pozbawiony nóg przez swojego rywala Vilhjálmra, to jednak inne przymioty rekompensują jego niedostatki fizyczne oraz pozwalają zapobiec potencjalnemu kryzysowi męskości. Hrólfr oraz inni bohaterowie sagi są nadto uwikłani w sieć przysiąg i przyrzeczeń, które wykorzystuje się, w myśl interpretacji Lavendera, jako element nacisku i oręż w podporządkowywaniu innych mężczyzn bądź ograniczaniu ich władzy.

${ }^{6}$ „A critique of the homosocial court of King Karl” (s. 84). 
Problem władzy rozważa także Ásdís Egilsdóttir w treściwym szkicu $M a$ sculinity, Christianity, and (Non)Violence, rozpatrując go w optyce przyjęcia przez Islandię chrześcijaństwa (w 999 lub 1000 roku), które to wydarzenie doprowadziło do wykształcenia się nowego typu męskości, alternatywnego wobec modelu heroicznego. Odwołując się m.in. do przekazów o Porláku Pórhallssonie, Jónie Ögmundarsonie i Guðmundzie Arasonie, Ásdís analizuje męskość duchownych, którzy odgrywali rolę rozjemców i orędowników pokoju oraz wzbraniali się przed zbrojnym rozwiązywaniem sporów. Autorka wykazuje, że pokojowe sposoby rozwiązywania konfliktów, zgodne z chrześcijańskim przesłaniem, cieszyły się społecznym uznaniem. Mimo że ówcześni ludzie Kościoła nie stosowali przemocy, to jednak dzięki odwadze i sile charakteru dowodzili swojej męskości i zdobywali autorytet.

Thomas Morcom w artykule Inclusive Masculinity in Morkinskinna and the Defusal of Kingly Aggression omawia relacje między władcą a królewską świtą (hird) w sagach o królach Norwegii, zawartych w trzynastowiecznym manuskrypcie Morkinskinna. Hirð, czyli elitarna formacja, złożona na ogół z samych mężczyzn, skupiona wokół króla ucieleśniającego niedościgniony ideał mężczyzny, funkcjonowała jako inkluzywny konglomerat wielu typów męskości, począwszy od aktywnych i agresywnych męskości ortodoksyjnych, a skończywszy na pasywnych i roztropnych męskościach alternatywnych. Wedle Th. Morcoma zarówno hipermęskie formy męskości, jak i męskości alternatywne koegzystują na równych prawach w ramach hirð. Analizując wybrane epizody sagi o królu Sigurdzie I, badacz udowadnia, że przedstawiciele tego drugiego wariantu męskości niejednokrotnie temperują agresywne oraz (auto)destrukcyjne emocje i zachowania dominujących władców.

Brynja Porgeirsdóttir w interesującym tekście Emotions of a Vulnerable Viking: Negotiations of Masculinity in Egils saga usiłuje zgłębić stany emocjonalne jednej z najwyrazistszych postaci męskich w literaturze staronordyckiej, Egilla Skalla-Grímssona. Podkreślając dwoistą naturę protagonisty, brutalnego wojownika i wrażliwego poety, Brynja skupia się na emocjach, które targają Egillem - od melancholii po chorobę miłosną. Badaczka wykazuje analogie między opisami psychicznego cierpienia bohatera a reprezentacjami melancholii i amor heroes $\mathrm{w}$ arturiańskich romansach Chrétiena de Troyes oraz Lais Marie de France, przetłumaczonych (czy, bezpieczniej powiedzieć, zaadaptowanych) na język staronordycki w XIII stuleciu. Brynja zwraca uwagę na fakt, że intensywne stany emocjonalne Egilla idą najczęściej w parze z natchnieniem poetyckim, wszak tworzenie poezji stanowi dlań remedium na psychiczne udręki. Przypominając, że choroba miłosna dotykała w średniowieczu głównie osoby z wyższych warstw społecznych, autorka stwierdza, że nadmierna emocjonalność Egilla w tej materii nie kwestionowała jego męskości, lecz ją nobilitowała. 
Do symboliki níð w Bjarnar saga Hitdcelakappa powraca po latach znamienita thumaczka i interpretatorka tej sagi rodowej Alison Finlay ${ }^{7} \mathrm{w}$ pracy zatytułowanej 'Pat pótti illr fundr': Phallic Aggression in Bjarnar saga Hitdcelakappa. Finlay przywołuje znany epizod sagi, w którym pojawia się níð, czyli prawnie zabroniona, dotkliwa zniewaga $\mathrm{w}$ formie werbalnej lub wizualnej, zasadzająca się na zakwestionowaniu męskości rywala poprzez zasugerowanie jego pasywnego udziału w akcie homoseksualnym. Podpierając swoją analizę wątku z udziałem Bjǫrna i Pórðra innymi przykładami z literatury staronordyckiej, autorka podkreśla obopólny charakter nið — hańbą okrywa się zarówno mężczyzna znieważany, jak i znieważający (s. 174).

W innym świetle relacje między mężczyznami przedstawia David Ashurst $\mathrm{w}$ Male Bedpartners and the 'Intimacies of a Wife': rekkjufélagar and vifs rúnar. Opierając swój wywód na obszernym materiale źródłowym, składającym się w głównej mierze z sag królewskich oraz wybranych sag rodowych, rycerskich i legendarnych, autor podejmuje kwestię mężczyzn, którzy dzielą wspólną przestrzeń sypialną. Przytacza on chociażby przekazy o królach, którzy pozwalali sypiać w tym samym pomieszczeniu swoim podwładnym. D. Ashurst twierdzi, że dzięki tej praktyce mężczyźni zacieśniali między sobą więzi emocjonalne, które niejednokrotnie stanowiły fundament zażyłej przyjaźni. Jak słusznie zaznacza, relacji tych nie należy jednakże łączyć z pożądaniem seksualnym.

Zagadnienie męskości duchownych, sygnalizowane wcześniej przez Ásdís, problematyzuje również, na kanwie sagi o Laurentiusie Kálfssonie, Carl Phelpstead w Companions, Conflicts, and Concubines: Clerical Masculinities in Lárentíus saga biskups. Badacz zauważa, że świat przedstawiony w sadze o biskupie diecezji w Hólar (w latach 1324-1331) jest nieomal całkowicie zdominowany przez mężczyzn, co stwarza podatny grunt zarówno dla konfliktów, jak i przyjaźni. Jak uzasadnia, przyjaźnie w utworze mają charakter hierarchiczny (są zawiązywane między duchownymi różnych szczebli) i afektywny (opierają się na mocnej więzi emocjonalnej). Ten zamknięty męski krąg, w którym kobiety odgrywają marginalną rolę, jest jednocześnie polem zatargów między należącymi doń mężczyznami. Według autora w Lárentíus saga konflikty tworzą się w obrębie tej samej społeczności, w przeciwieństwie do innych sag biskupich, które na ogół tematyzują spory między duchownymi a osobami świeckimi (s. 211).

Tom zamyka artykuł Jessiki Clare Hancock 'That which a hand gives a hand or a foot gives a foot': Male Kinship Obligations in the Heroic Poetic Edda and Völsunga saga, dotyczący relacji między mężczyznami na niwie rodzinnej. Autorka wychodzi od figury ojca, która to postać odgrywa istotną

${ }^{7}$ Zob. m.in.: A. Finlay: Ní, Adultery and Feud in Bjarnar saga Hitdcelakappa. "SagaBook" 1990-1993, Vol. 23, s. 158-178; The Saga of Bjorn, Champion of the Hitardal People. Trans. A. Finlay. In: The Complete Sagas of Icelanders. Vol. 1. Reykjavík 1997, s. 255-304. 
rolę w kształtowaniu męskiej tożsamości synów (rodzonych lub przybranych), będąc dostarczycielem wzorców i zachowań składających się na męskość heroiczną (heroic masculinity - s. 219). Przytaczając liczne przykłady ojcobójstwa i bratobójstwa, J.C. Hancock kieruje uwagę na negatywne aspekty heroicznego modelu męskości, opartego na stosowaniu przemocy i konieczności zemsty, niejednokrotnie prowadzącego do destrukcyjnej międzypokoleniowej rywalizacji o męski prymat oraz do napięć na linii ojciec — syn lub brat — brat.

Gwoli podsumowania wypada mieć nadzieję, że ten zgrabny, różnorodny tematycznie tom pociągnie za sobą kolejne publikacje z zakresu coraz prężniej rozwijających się studiów nad mężczyznami i męskościami w literaturze staronordyckiej. Niezaprzeczalnym atutem książki pod redakcją G.L. Evansa i J.C. Hancock jest fakt, że zarówno zagadnienia podejmowane w poszczególnych artykułach, jak i analizowane teksty literackie zostały ubrane w nowe szaty, dzięki czemu wyprowadzone przez autorów wnioski interpretacyjne nie tchną wtórnością. Szczególną wartość mają rozważania na temat męskości w sagach biskupich, które nie zostały dotąd gruntownie przebadane pod tym kątem, a także szkice poruszające ważki (i modny ostatnimi czasy ${ }^{8}$ ) temat związany z przeżyciami emocjonalnymi męskich bohaterów sag. Ciekawie wypadają również spostrzeżenia dotyczące korelacji pomiędzy męskością a niepełnosprawnością, dające pole do analizy intersekcjonalnej ${ }^{9}$. Mimo że autorzy szkiców stosują, jak to zwykle bywa w przypadku tomów zbiorowych, odmienne metody analizy tekstowej, to jednak łączy ich wspólny mianownik, którym są narzędzia teoretyczne, zapożyczone ze współczesnych badań nad męskościami. Owe narzędzia, testowane już wcześniej przez badaczy sag ${ }^{10}$, po raz pierwszy zastosowano w badaniach nad całą literaturą staronordycką, a eksperyment ten uznać trzeba za udany i obiecujący. Instrumentarium teoretyczne, z którego chętnie korzystają autorzy, wydaje się skuteczne operacyjnie i umożliwia wieloaspektowy ogląd różnych wariantów męskości.

\section{Radosław Jakubczyk}

(iD https://orcid.org/0000-0001-5642-1611 Wydział Filologiczny, Uniwersytet Jagielloński

${ }^{8}$ Zob.: K. Wolf: Somatic Semiotics: Emotion and the Human Face in the Sagas and pattir of Icelanders. "Traditio" 2014, Vol. 69, s. 125-145; Sif Rikhardsdottir: Emotion in Old Norse Literature: Translations, Voices, Contexts. Cambridge 2017.

${ }^{9}$ W tym duchu analizuje sagi G.L. Evans: Men and Masculinities..., s. 87-91.

10 Zob. np.: C. Phelpstead: The Sexual Ideology of Hrólfs saga kraka. "Scandinavian Studies" 2003, Vol. 75, no 1, s. 1-24; D. Clark: Gender, Violence, and the Past in Edda and Saga. Oxford 2012; G.L. Evans: Men and Masculinities... 